
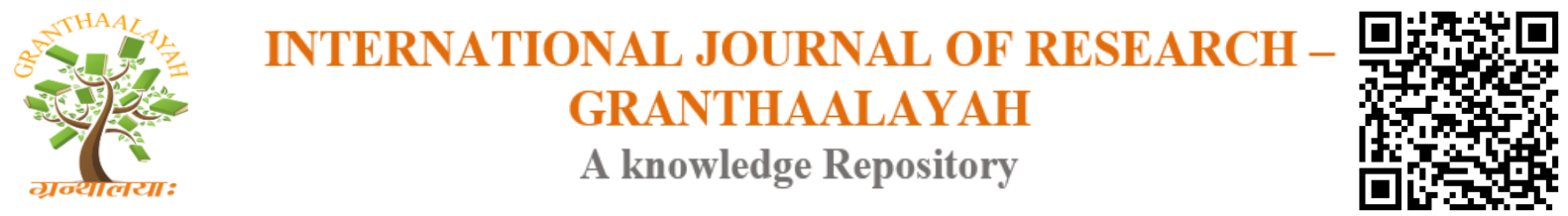

Management

\title{
INTELLECTUAL CAPITAL IN INNOVATIVE FIRM
}

\author{
Nurziana Mohd Atan *1, Saudah Sofian ${ }^{2}$ \\ ${ }^{* 1,2}$ Faculty of Management, Universiti Teknologi Malaysia, Malaysia
}

\begin{abstract}
This research was conducted to investigate the influence of intellectual capital on overall innovation and R\&D activities in an innovative firm. The firm is a leader in natural goat's milkbased cosmetics and health products in Malaysia. Intellectual capital consists of four components, human capital, structural capital, relational capital and spiritual capital. This research was a case study and qualitative approach was applied to gather data. The Marketing Manager, Human Resource Manager, Factory Operation Manager, administrative workers, factory workers, IT personnel and customers of the firm were interviewed. The information from the interviews was analyzed using codes and transcription. Finding of the study indicates that among the intellectual components, structural capital is the highest contributor to the firm's innovation. Among the recommendations made to the firm are to increase human capital with high expertise, to have a systematic documentation, to cooperate with organization's external environment and strengthen spiritual value. Future researches are suggested to use instruments other than interviews and widen the scope to more than one firm or industry.
\end{abstract}

Keywords: Intellectual Capital; Human Capital; Structural Capital; Relational Capital; Spiritual Capital; Innovation.

Cite This Article: Nurziana Mohd Atan, and Saudah Sofian. (2017). "INTELLECTUAL CAPITAL IN INNOVATIVE FIRM." International Journal of Research Granthaalayah, 5(11), 366-373. https://doi.org/10.29121/granthaalayah.v5.i11.2017.2369.

\section{Introduction}

In a fully competitive world, intangible assets are very important for an organization (Stewart, 1999). This is because in the 21st century, economy requires high investments in knowledge assets such as information technology, Internet business, brands, patents, and copyrights. These knowledge assets are also known as intellectual assets or Intellectual Capital (IC) (Seetharaman et al., 2002; Dean and Kretschmer, 2007). In business, success will only be achieved by a company that has good knowledge and uses it effectively. Wal-Mart, Microsoft and Toyota become great international companies because they have high IC, something more valuable than physical assets (Stewart, 1999). IC's existence is fundamental to the success of the organization in this century (Wiig, 1997). IC becomes a critical resource for the viability and success of the firms as it has an impact on business performance (Bontis, 1998; Bontis et al., 2002). 
This research focused on the firm that manufactures natural goat milk-based cosmetics and health products purely made in Malaysia. A scientific study has been done on goat's milk and it has been endorsed by qualified researchers that it contains enzymes and vitamins and act as natural antibodies to help treating variety of internal and external diseases. This firm uses goat's milk soap processing machines (soap press), which is high-tech, the main element that creates value (Carroll and Tansey, 2001) and competitive advantage of the firm (Collins and Montgomery, 1995). The firm's products have their own uniqueness and they are free from artificial and hazardous chemicals. Formulas and modern technology are applied as innovation to further strengthen the company's excellence in local and international markets. This research was carried out to find out how IC influences the performance of the firm, which is considered innovative.

IC is gaining firms' attention in leading their activities in order to be more valuable. Therefore, the firms need to pay attention to IC and its components and apply it strategically. Employees, as human capital, are responsible to perform activities of the firm. There is no doubt that they have the skills and experience of their own. Since this firm is innovative, it is important and interesting to find out how they use existing assets of the firm to generate revenue. Knowledge and ideas are then transformed into physical form and later commercialised. The challenge here is to sustain the human capital so that they continue generating knowledge and ideas (Roos et al., 1997). Customers are important to this firm, however, their satisfaction is difficult to maintain. Customer satisfaction should be sustained if the firm wants to keep good relationship with them. Thus, this study investigated how this innovative firm apply IC to keep its customers happy and loyal. Ethics is also emphasized among the employees in order to carry out the firm's business transaction as well as their earnestness and enthusiasm in achieving sales target. These IC components is directly related with the firms' innovation as today it has become very critical and is a priority in all aspects of the business. Apart from that, product innovation highly depends on IC. With the challenges of globalization today, every business needs to complete the science of innovation in products and services in order to compete locally and internationally. This prompted the study to examine how the firm develops innovative IC.

This study examines the use of IC and innovation in an innovative firm. Intellectual capital components were studied in detail and the role of innovation was also investigated. The objectives of this study were:

1) To examine the use of IC in an innovative firm.

2) To learn how to do product innovation in an innovative firm.

3) To assess how the firm develops innovation capital.

\subsection{Literature Review}

IC is divided into four components, namely human capital, structural capital, relational capital and spiritual capital (Bontis, 1998).

Human capital consists of knowledge, education, skills and characteristics of members of the organization (Edvinsson and Malone, 1997). It is the ability of an organization to act with skills and generate value for the firms. It is regarded as the most important element of IC and a firm will not succeed without it. Guthrie (2001) stated that Human Capital contains all the assets of 
knowledge (tacit and explicit) that exist within individuals. Human capital includes not only the necessary knowledge and skills, but also the relationship with other employees for the creation of a working group within the organization. At the same time, Human capital is defined as the knowledge, information, communication, and general capabilities brought by individuals on behalf of the firm through an employment relationship (Galunic and Anderson, 2000). For Bontis (1998), Human capital is a collective ability of the firms to produce the best solutions from the knowledge of the individuals.

The Structural capital of an organization is defined as knowledge that remains in the firms even though the employees are no longer members of the firms (Roos et $a l ., 1998$ ). It relates to the structure and information systems which can lead to intellectual business. Human capital is the primary factor for developing the structural capital. Therefore, structural capital depends on human capital. According to Skandia (1994), Structural capital is the ability in organization, organizational commitment, knowledge management system, technology systems, databases, institutional arrangement, the operation, maintenance philosophy, organizational culture, reputation image, patents, copyrights, and trademarks. Bounfour (2003) stated that structural capital is differed from tacit human knowledge, the examples are patents, trademarks and licenses, databases and all other items related to procedures and software. In addition, Collins and Montgomery (1995) stated that the structural capital increases because of its contribution to the creation of competitive advantage. Similarly, Ramirez et al. (2007) stated that the structural capital is explicit knowledge related to internal processes deployment and management of scientific and technical knowledge.

Relational capital refers to the ability of organizations to interact in positive manners with outsiders and creating wealth creation potential of human capital and structural capital. It requires resources associated with the external relations of the firms such as relationships with customers, suppliers, partners, and local communities as well as the knowledge that underlies this relationship (Sveiby, 1997; Edvinsson and Malone, 1997; Bontis, 1998). It is also understood as social capital that focuses on linkages created by the organization (Nahapiet and Ghoshal, 1998). Relational Capital exists in the partnership formed by the organization and includes the relationships with customers and businesses, industries and community relations (Moon and Kym, 2006).

Spiritual capital is the intangible knowledge, beliefs and emotions contained in the minds and hearts of individuals and organizations which involve vision and direction, principles, values and culture. It also involves motivation, confidence, enthusiasm, strength, commitment, teamwork, desire, and passion to work in groups (Mazlan, 2005). Zohar and Marshall (2004) defined spiritual capital as an asset that helps strengthen the future of mankind and also perpetuate the human spirit. It is used in communities or organizations aspirations and their responsibilities. Spiritual capital can be considered as the amount of knowledge and expertise related to the purposes, values and goals that are on individual basis. It covers all aspects of psychological, moral and spiritual knowledge and expertise.

Innovation research provides the elements that add commercial value that is element used by the firm to develop products (Porter, 1990). One way for the firm to innovate is through product innovation. Product innovation is defined as the process of updating and improving products, 
processes, materials and services that are developed and converted to the appropriate market (White and Bruton, 2007). It is considered essential because the idea or creation of something new that affects the changes of final product or services offered by the organization.

Improvement process and product innovation are from the technical knowledge resulting from research and development (R\&D) carried out in the firms (Pablos, 2004). Therefore, R\&D is always done on a continuous basis in the company because it was able to improve the product from all aspects and the opportunities to maintain their competitive advantage is higher. Innovation allows diversification strategy used by the organization. This firm has been able to produce the very first goat milk formula. This is the result of collaboration with a laboratory in France. The product development process is conducted so that innovation can be done on new products or existing products. The firm obtained help from government agencies and statutory bodies such as the Veterinary Office to provide advisory service on livestock namely goats that became the basic source material for the product. An international laboratory in France also provides help to this firm by sharing expertise in producing goat's milk pills formula.

\section{Methodology}

This study was qualitative. Data were obtained through interviews with respondents in an innovative firm. Data analysis was conducted by the process of transcribing, coding and categorizing from interviewees answer scripts. The purpose of qualitative research is to select information which can give the best answer to the research question. In this type of research, data is obtained qualitatively from interviews, observations, archival documents such as reports, magazines and company budgets. The total of interviewees was 25 . They were among marketing manager, operation manager, finance manager, product development manager and human resource manager, company employees, stockists, customers and consumers. The management was selected because they were involved directly in the internal and external activities of the organization and have broad knowledge of the organization.

\section{Results and Discussions}

\subsection{The Use of IC in Innovative Firm}

The results obtained indicate that the employees are research experts who constantly making new discoveries to produce better quality products for the benefit of users. Examples of the products are goat's milk tablet and supplement drinks. The experts have many years of experience from their previous job in large corporations in Malaysia. This is in line with Miller (1999) who suggested that with the existence of individuals, who are expert, experienced and capable, firms can be innovative create value.

In term of structural capital, this firm keeps information on the related people to the firm such as customers, in its database. An online system is used to facilitate product orders from members, distributors and stockiest (who become agents to market the firms' products), records information's pertaining to purchases and sales, as well as product distribution process (Andriessen, 2001). The routines and processes within the firm are carried out effectively; it can provide a better service to customers (Bontis et al., (2002). The technology process to 
manufacture a product being documented, stored and recorded in the database so that it remains as the firms' structural capital (Andriessen, 2001). Distributors are channelled for the firm's products to reach consumers. The relationship is not solely a business based, but they involve long association with suppliers, cooperation with government agencies and social responsibility to the community. This shows that the firm is emphasizing the importance of building good relationships because firm is interdependent and interact with each other in an organizational setting (Bontis, 1998). Relations with competitors are not left out because the firm also manufactures products for other firms.

Spiritual capital also helps build up innovation in this firm. Rewards and bonuses are given as a way to show appreciation and give motivation to attain the company goals. Members of the firm have the awareness and intention to succeed in life. In order to achieve that, they passionately perform the business activities as it is their responsibilities to ensure that the firm can reach its goal (Wilber, 1996). They know the success in life can be achieved through their work environment (Chang et al., 2008). In conclusion, the results showed that to understand and develop the different types of IC, firms need to create unique and new paths for innovation. When the firm understands the value and the important of innovation, it can automatically align the uniqueness that will be added in their future product with the abilities of IC that the company have.

\subsection{The Development of IC in Innovative Firm}

The results showed that IC is fully utilized within the studied firm. All components of IC are indeed applied in this innovative firm. Through organization learning, individuals in the company can share their knowledge (Bontis et al., 2000). This firm is looking after the welfare of its employees because the firm knows that they are important assets that drive business activities. As stated by Marta (2009), employees' knowledge leads to the good quality of production, as they knew what the benefits that can be obtained from certain products. To ensure that employees in the company really has the knowledge and expertise they need to go through a recruiting process that takes into account several criteria such as experience and background knowledge about their field of expertise.

In term of product patents, the firm established a system of patent protection which can prevent the occurrence of products counterfeit cases in the market (Carroll and Tansey, 2001). The firm is also working with government bodies such as Federal Agriculture and Marketing Authority (FAMA) to obtain supplies of raw materials, namely goat's milk. The firm is also creating a marketing plan which is designed to increase employee motivation and a considerable portion of the firm's profits can be distributed to distributors and qualified recognized members. The firm is constantly monitoring the progress of distributor's activities so that discussion and ideas exchange can be made in order to motivate them to continue their business activities while making a contribution to the consumers (Barney, 1991).

\subsection{Product Innovation in Innovative Firm}

The findings indicate that the firm's product, which is goat's milk tablet, is designed to meet the needs of the market. All the deficiencies that exist in each product are taken into account by 
getting the feedback from customers. Each of their comments and views is recorded and the extent of their truth and rationale is analyzed. Improvement process of the product innovation is a technical knowledge resulting from R\&D done in this firm (Pablos, 2004). Therefore, R\&D has always been done continuously because it will improve the product and the opportunity to maintain competitive advantage is higher.

The new discovery, namely the production of goat's milk from liquid to powder form and goat's milk are innovations which led by the firm. This innovation eliminates the disadvantages of liquid milk. Goat's milk soap is another important product of this innovative firm. Some ingredients of the milk help to smooth the skin and prevent its dullness. That the firm does compliment Herkema (2003) who noted that innovations involve a lot of changes to the product in terms of improvement and diversity. At the early establishment of this firm, there were only eleven types of cosmetics and health products. This firm dared to create something new that goat milk can be commercialized in various forms of pills and cosmetics. The commercial value should be used as a strategy especially for companies that manufacture products for consumers and communities.

\section{Conclusions and Recommendations}

As for future research directions, it is recommended that spiritual capital be given greater attention to be studied because it is closely related to the human soul, even though there is still no strong theory regarding this IC component. This study was conducted through interviews and study of archival documents but method can be expanded to other instruments such as observation and visual materials. This type of study can also be conducted in other types of firms that also have high investment in IC. It would also be interesting to work with secondary data, and other types of innovation, such as process innovation. This is because different types of innovation require the use and management of different resources within the firm.

\section{References}

[1] Andriessen, D. (2001). Weightless Wealth: Four Modifications to Standard IC Theory. Journal of Intellectual Capital. 2(3): 204-14.

[2] Bennet, A. dan Bennet, D. (2007). The Knowledge and Knowing of Spiritual Learning. The Journal of Information and Knowledge Management Systems. 37(2): 150-168.

[3] Bergfors, M.E. dan Larsson, A. (2009). Product and Process Innovation in Process Industry: A Newperspective on Development. Journal of Strategy and Management. 2(3):261-276.

[4] Bollinger, A.S. dan Smith, R.D. (2001). Managing Organizational Knowledge as a Strategic Asset. Journal of Knowledge Management. 5(1): 8-18.

[5] Bontis, N. (1998). Intellectual Capital: An Exploratory Study that Develops Measures and Models. Management Decision. 36(2):63-76.

[6] Bontis, N., Crossan, M.M. dan Hulland, J. (2002). Managing an Organizational Learning System by Aligning Stocks and Flows. Journal of Management Studies. 39(4):43-69.

[7] Bounfour, A. (2003). The IC-dVal Approach. Journal of Intellectual Capital. 4(3): 396-412.

[8] Carroll, R.F. dan Tansey, R.R. (2001). Intellectual Capital in the New Internet Economy: Its Meaning, Measurement and Management for Enhancing Quality. Journal of Intellectual Capital. 1(4): 296-311.

[9] Chang, H.T., Yang, W.H. dan Lin, Y.C. (2008). International Conference on Business and Information. South Korea. 
[10] Collins, D.J. dan Montgomery, C.A. (1995). Competing on Resources: Strategy in the 1990s. Harvard Business Review. 73(4): 118-128.

[11] Damanpour, F. dan Gopalakrishnan, S. (1996). Theories of Organizational Structure and Innovation Adoption: The Role of Environmental Change. Journal of Engineering and Technology Management. 15(1): 1-24.

[12] Das, T. K. dan Teng, B.S. (2000). A Resource-Based Theory of Strategic Alliances. Journal of Management. 26(1): 31-61.

[13] Dean, A. dan Kretschmer, M. (2007). Can Ideas Be Capital? Factors of Production in the Postindustrial Economy: A Review and Critique. Academy of Management Review. 32(2).

[14] Edvinsson, L. dan Malone, M. (1997). Intellectual Capital: The Proven Way to Establish Your Company's Real Value by Measuring Its Hidden Brainpower. London: Piatkus.

[15] Guthrie, J. dan Petty, R. (2000). Intellectual Capital: Australian Annual Report Practices. Journal of Intellectual Capital. 1(3): 24-51.

[16] Guthrie, J. (2001). The management, Measurement and The Reporting of Intellectual Capital. Journal of Intellectual Capital. 2(1): 27-41.

[17] Galunic, C.D. and Anderson, E. (2000). From Security to Mobility: Generalized Investments in Human Capital and Agent Commitment. Organization Science. 11(1): 1-20.

[18] Kianto, A. (2007). What do we really mean by dynamic intellectual capital?International Journal of Learning and Intellectual Capital. 4(4): 34-56.

[19] Miller, W. (1999). Building the Ultimate Resource. Management Review. 8(2): 42-45.

[20] Miriam Delgado-Verde, Gregorio Martín de Castro, Jose Emilio Navas-Lopez and Javier Amores-Salvado. (2014). Vertical relationships, complementarity and product innovation: an intellectual capital-based view. Knowledge Management Research \& Practice. 226-235(12).

[21] Lager, T. dan Horte, S. (2002). Success Factors for Improvement and Innovation of Process Technology in Process Industry. Integrated Manufacturing Systems. 13(3):158-164.

[22] Lepak, D.P. dan Snell, S. (1999). The Human Resource Architecture: Toward A Theory of Human Capital Allocation and Development. Academy of Management Review. 24(1): 31-48.

[23] Mazlan Ismail. (2005). The Influence of Intellectual Capital on The Performance of Telekom Malaysia. Tesis Ph.D. Universiti Teknologi Malaysia.

[24] Mayo, A. (2000). The Role of Employee Development in the Growth of Intellectual Capital. Personnel Review. 29(4): 521-533.

[25] Moon, Y.J. dan Kym, H.G. (2006). A Model for the Value of Intellectual Capital. Canadian Journal of Administrative Science. 23(2): 53-69.

[26] Nahapiet, J. dan Ghoshal, S. (1998). Social Capital, Intellectual Capital and The Organizational Advantage. Academy of Management Review. 23(2): 24-66.

[27] Nonaka, I. dan Takeuchi, H. (1995). The Knowledge Creating Company. Oxford: Oxford University Press.

[28] Nonaka, I. (1994). A Dynamic Theory of Organizational Knowledge Creation. Organization Science. 5(1):14-37.

[29] Pablos, P.O. (2004). Measuring and Reporting Structural Capital. Journal of Intellectual Capital. 5(4): 629-647.

[30] Shariq, S.Z. (1997).Knowledge Management: An Emerging Discipline. Journal of Knowledge Management. 1(1): 75-82.

[31] Porter, M.E. (1990). The Competitive Advantage of Nations. London: MacMillan. 33.Priem, R. L., and Butler, J. E. (2001). Is The Resource-Based View A Useful Perspective For Strategic Management Research? Academy of Management Review. 26(1): 22-40.

[32] Ramirez, Y., Lorduy, C. dan Rojas, J.A. (2007). Intellectual Capital Management in Spanish Universities. Journal of Intellectual Capital. 8(4): 732-748.

[33] Reinhardt, R., Bornemann, M., Pawlowsky, P. dan Schneider, U. (2003). Intellectual Capital and Knowledge Management: Perspectives on Measuring Knowledge. In: Dierkes, M., Antal, A., 
Child, J. dan Nonaka, I. Handbook of Organizational Learning and Knowledge. Oxford University Press: Oxford. 794-820.

[34] Roos, J., Roos, G., Edvinsson, L. dan Dragonetti, N.C. (1998). Intellectual Capital: Navigating In the New Business Landscape. New York, NY: New York University Press.

[35] Skandia. (1994). Visualising Intellectual Capital in Skandia. A Supplement to Skandia's 1994 Annual Report. Sweden: Skandia.

[36] Sveiby, K. (1997). The New Organizational Wealth: Managing and Measuring Knowledgebased Assets. San Francisco, CA: Berrett-Koehler Publishers.

[37] Stewart, T. (1999). Intellectual Capital: The New Wealth of Organizations. New York: Bantam Books.

[38] Seetharaman, A., Zaini Soria, H.H., dan Saravanan, A.S. (2002). Intellectual Capital Accounting and Reporting in the Knowledge Economy. Journal of Intellectual Capital. 3(2): 128-148.

[39] White, M.A. dan Bruton, G.D. (2007). The Management of Technology and Innovation: A Strategic Approach. Thomson South-Western: Canada.

[40] Wiig, K.M. (1997). Knowledge Management: An Introduction and Perspective. Journal of Knowledge Management. 1(1): 6-14.

[41] Wilber, K. (1996). A Brief History of Everything. Boston MA: Shambala.

[42] Zohar, D. dan Marshall, I. (2004). Spiritual Capital: Wealth We Can Live. San Francisco, CA: B. Berrett- Koehler Publishers.

\footnotetext{
*Corresponding author.

E-mail address: zyane_hazels@yahoo.com
} 